\title{
Measurement of masticatory forces in the horse
}

\author{
Carsten Staszyk', Frank Lehmann², Astrid Bienert ${ }^{3}$, Klaus Ludwig ${ }^{2}$ and Hagen Gasse \\ Institute of Anatomy, University of Veterinary Medicine Hannover ${ }^{1}$, Clinic of Prosthodontics, Propaedeutics and Dental Materials, \\ University Hospital Schleswig-Holstein, Campus Kiel${ }^{2}$ and Clinic for horses, University of Veterinary Medicine Hannover ${ }^{3}$
}

\begin{abstract}
Summary
To measure the forces of the equine chewing cycle, which comprises three distinct phases: (1) opening stroke: downward and sideward movement of the mandible; (2) closing stroke: initial occlusion of the cheek teeth; (3) power stroke: laterolateral grinding movement. No data has yet been available about the forces exerted during the distinct phases of equine chewing. However, such physical data will advance investigations in equine nutrition, dentistry, and mandibular surgery. Measuring equipment: a quartz crystal force sensor was embedded in a nylon capsule and connected to a handgrip of steel tubing containing the wiring. Animals: 12 warmblood horses (6 female, 6 male, between 5 and 27 years old). The sensor was placed on the second or third premolar teeth of the lower jaw (Triadan: 306/307, and 406/407). The data measured during mastication were transferred to a computer equipped with an analysis system. Two peaks of masticatory forces were recorded during a single chewing cycle: (1) an initial minor peak of $248 \pm 117 \mathrm{~N}$, duration $0.27 \pm 0.08$ sec. (2) a major peak of $875 \pm 278 \mathrm{~N}$, duration $0.59 \pm 0.13 \mathrm{sec}$. Chewing rate: $8 \pm 1$ chewing cycles per $10 \mathrm{sec}$. Maximum chewing force: $1758 \mathrm{~N}$. During the measuring procedure, the horses showed regular chewing cycles. The recorded force time graphs revealed two different periods of force generation (peak 1:248 N; peak 2:875 N). This pattern reflects well the distinct phases of the chewing cycle. Peak 1 corresponds to the closing stroke; peak 2, to the power stroke.
\end{abstract}

Keywords: masticatory forces, chewing cycle, force sensor, cheek teeth, horse

\section{Messung von Kaukräften des Pferdes}

Der Kauzyklus des Pferdes besteht aus drei einzelnen Kauphasen: 1. Maulöffnung - der Unterkiefer wird abwärts und gleichzeitig seitwärts bewegt; 2. Kieferschluss - der Unterkiefer wird aufwärts bewegt, bis Ober- und Unterkieferbackenzähne miteinander in Kontakt kommen; 3. Mahlbewegung - laterolateral gerichtete Bewegung des Unterkiefers. Angaben über die auftretenden Kaukräfte in den einzelnen Kauphasen sind bisher nicht verfügbar. Entsprechende Daten werden allerdings als Grundlage für Untersuchungen in verschiedenen Fachbereichen benötigt: a. In der Tierernährung - zur Beurteilung mechanischer/abrasiver Eigenschaften von Futtermitteln. b. In der Zahnheilkunde - zur Ermittlung der Widerstandsfähigkeit und Belastbarkeit des Zahns und seines Halteapparates. c. In der Kieferchirurgie - zur Entwikklung chirurgischer Techniken für restaurative Korrekturen (Frakturen / Fehlbildungen der Mandibula) sowie insbesondere zur Entwicklung geeigneter chirurgischer Instrumente und Hilfsmittel (inkl. Materialkunde). Messgerät: Ein Quarzkristall-Kraftsensor (Kistler AG, Winterthur, Schweiz) wurde in eine Nylonkapsel eingebettet und diese mit einem Handgriff aus Stahlrohr versehen. Durch den Stahlrohr-Handgriff wurde die Verkabelung geführt. Pferde: 12 Großpferde (6 weiblich, 6 männlich, im Alter von 5 bis 27 Jahren). Durchführung der Messungen: Mittels Handgriff wurde der Kraftsensor auf dem zweiten oder dritten Prämolaren des Unterkiefers (Triadan: 306/307 und 406/407) platziert und während der Kaubewegung in dieser Position gehalten. Die Messdaten wurden von einem angeschlossenen Computersystem aufgezeichnet. Während eines Kauzyklus wurden zwei Peaks von Kaukräften aufgezeichnet: 1. Peak 1: $248 \pm 117$ N, Dauer $0.27 \pm 0.08$ sek. 2. Peak 2: $875 \pm 278$ N, Daver $0.59 \pm 0.13 \mathrm{sec}$. Kaufrequenz: $8 \pm 1$ Kauschläge pro 10 sek. Die höchste gemessene Kaukraft betrug 1758 N. Während der Messungen zeigten die Pferde regelmäßige und natürliche Kaubewegungen. Die aufgezeichneten Kraft-Zeit-Kurven wiesen zwei verschiedene Perioden der Kaukraftentstehung auf (Peak 1: 248 N, Peak 2: 875). Dieses Zweistufenmuster findet seine Entsprechungen in den einzelnen Phasen des Kauzyklus. Peak 1 bildet die Phase des Kieferschluss ab und Peak 2 entspricht der Phase der Mahlbewegung.

Schlüsselwörter: Kaukräfte, Kauzyklus, Kraftsensor, Backenzähne, Pferd

\section{Introduction}

There is a need for specific data on equine mastication in several fields: (1) In nutritional science, the disruption of the forage is crucial to sufficient energy uptake in the horse (Frape 1990). (2) In mandibular/oral surgery, knowledge about the motions of the jaws and about chewing forces is necessary for the development of techniques and materials for the treatment of mandibular fractures and malformations. (3) In equine dentistry, physical data about mastication are required for investigations of the resilience of the tooth, the periodontal ligament, and the materials used for therapy.
The movements of the equine jaws during feeding have been documented by video analysis (Collinson 1994). Chewing has been defined as a unilateral process performed either on the right or on the left side of the mouth. One chewing cycle comprises three distinct phases (Collinson 1994, Tremaine 1997, Baker 2005): (1) opening stroke: the mandible moves downwards and to the side (Fig. 1a); (2) closing stroke: the mandible moves upwards until the lower jaw teeth make contact with the maxillary teeth (Fig. 1b); (3) power stroke: the lower jaw teeth grind upon the upper jaw teeth in a lingual direction (Fig. 1c). 
The masticatory forces generated during molar contact occur in two different stages (closing stroke and power stroke) in two distinct directions (vertical and horizontal). However, the only available data about masticatory forces in the horse (Wallraff 1943, Ritter 1953) were recorded only during movement of

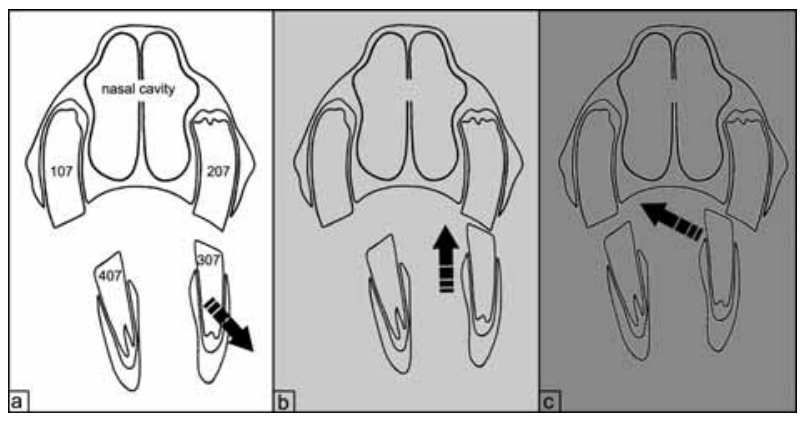

Fig 1 Schematic drawing of a transversal section through the head of a horse in order to demonstrate the three phases of the equine chewing cycle: (a) opening stroke; (b) closing stroke; (c) power stroke.

Schemazeichnung eines Transversalschnittes durch einen Pferdeschädel. Der Kauzyklus des Pferdes besteht aus drei Phasen: (a) Maulöffnung; (b) Kieferschluss; (c) Mahlbewegung.

the lower jaw into occlusion, i. e. during the closing stroke. As it is to be assumed that the dimensions of the masticatory forces are different in the distinct phases of equine mastication, we developed a method to measure masticatory forces during the entire chewing cycle.

\section{Material and Methods}

Animals

Masticatory forces were measured on 12 warmblood horses (6 female, 6 male) between 5 and 27 years of age (see Table 1 for details). Examination of the animals before measurement revealed no disorders or diseases of the teeth or the oral cavity.

Table 1 Investigated horses

\begin{tabular}{|c|c|c|c|}
\hline Horse & Body weight [kg] & Age [years] & Sex \\
\hline 1 & 520 & 5 & female \\
\hline 2 & 510 & 7 & female \\
\hline 5 & 550 & 7 & male \\
\hline 3 & 620 & 8 & male (gelding) \\
\hline 4 & 650 & 8 & male (gelding) \\
\hline 6 & 550 & 11 & female \\
\hline 7 & 520 & 11 & female \\
\hline 8 & 530 & 11 & female \\
\hline 9 & 600 & 12 & male (gelding) \\
\hline 10 & 540 & 18 & female \\
\hline 11 & 520 & 20 & male (gelding) \\
\hline 12 & 410 & 27 & male \\
\hline
\end{tabular}

Measuring equipment

A quartz crystal force sensor (Type 9132B, Kistler inc., Winterthur, Switzerland) was connected to a 300-mm-long hand grip of steel tubing which contained the wiring (Fig. 2a). The sensor was embedded in a u-shaped nylon capsule (Fig. 2b). Each nylon capsule was used for the examination of two horses. Each set was calibrated before use.

\section{Procedure}

The hand grip was used to place the sensor on the second or third premolar tooth of one side of the lower jaw (Triadan: $306 / 307$ or $406 / 407)$. The $u$-shaped bottom of the nylon

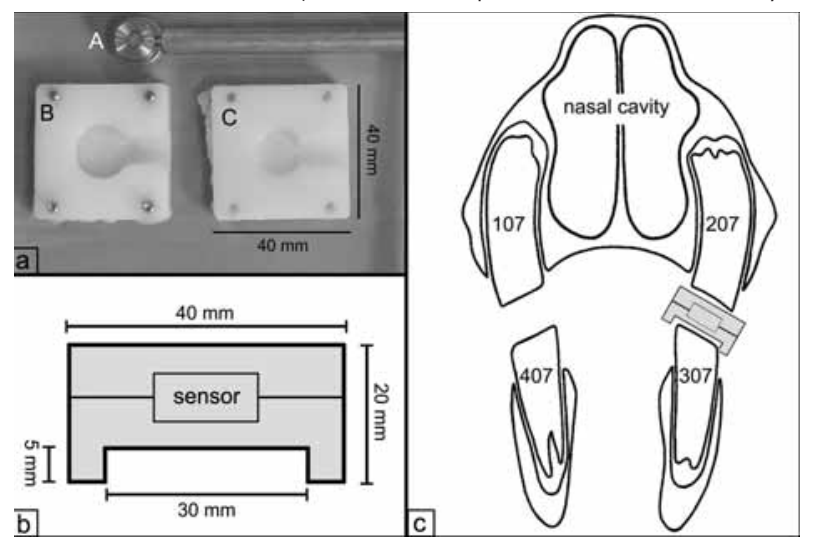

Fig 2 (a) Quartz crystal force sensor (A) to be placed between bottom (B) and cover (C) of a nylon capsule. (b) Front view of the nylon capsule (note the $30 \mathrm{~mm}$ wide carving which fits on the occlusal surface of the tooth). (c) Schematic representation of the position of the encapsulated sensor during the measurement. (a) Der Quarzkristall-Kraftsensor (A) wird in einer Nylonkapsel, bestehend aus Bodenplatte (B) und Deckelplatte (C), eingebettet. (b) Vorderansicht der montierten Nylonkapsel. Die Bodenplatte ist mit einer $30 \mathrm{~mm}$ langen Aussparung versehen, die auf die Okklusalfläche der Unterkieferbackenzähne aufgesetzt wird. (c) Schemazeichnung zur Darstellung der Sensorposition während der Messungen.

capsule held the sensor in position during the movements of the jaw (Fig. 2c and Fig. 3). Measurements were first performed on the left side of the jaw, and the sensor was removed from the oral cavity for $5 \mathrm{~min}$, when measurements were continued on the right side. Initially, the horses' chewing movements of the jaw and the tongue were irregular, but after approximately 2 min the animals accepted the sensor and started regular chewing cycles. The data measured during mastication were simultaneously visualized on a computer screen and transferred to an analysis system. The measuring equipment recorded the generated forces along a time axis.

\section{Results}

The recorded force time graphs showed a periodical sequence of two peaks during regular chewing cycles: a minor peak 1 was followed by a major peak 2 (Fig. 4). The periodical sequences of peak 1 and peak 2 were separated by intermediate periods of about $0.3 \mathrm{sec}$ in which no forces were generated (Fig. 4). Other sequences contained irregular peaks of various height. Only the periodical sequences of peak 1 and peak 2 were used for further calculations (force and duration of the peaks). The recorded force and duration were determined for each peak. Mean values for peak 1 and peak 2 were calculated for each individual horse (Fig. 5). The values of duration time were not significantly different (Multiple range test, Bonferroni correction). As for the masticatory forces, the values were significantly different only for two comparisons: horse 7 and horse 9, peak 1; horse 3 and horse 7, peak 2 (Multiple range test, Bonferroni correction). Subse- 
quently, mean values of duration time and masticatory forces were calculated for all horses (Fig. 6).

The mean force of peak 1 was $248 \pm 117 \mathrm{~N}$, ranging between $28 \mathrm{~N}$ (horse 7) and $615 \mathrm{~N}$ (horse 11); the mean duration

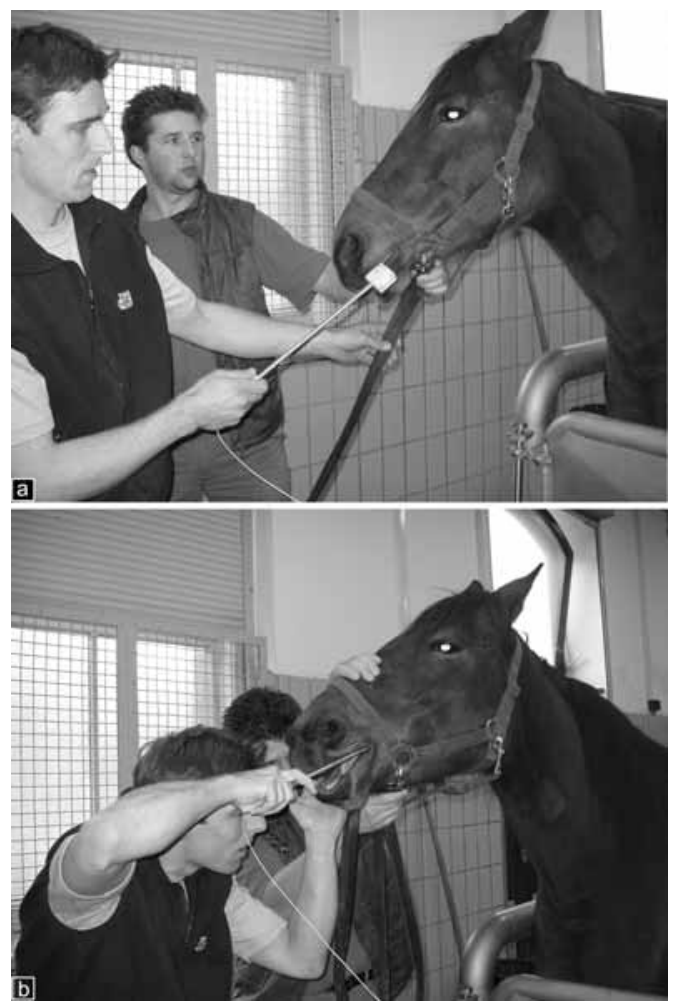

Fig 3 (a) The sensor was encased in a nylon capsule and connected to a hand grip of steel tubing which contained the wiring. (b) The sensor was placed on the lower second or third premolar tooth and held in position during the masticatory movements of the jaw. (a) Der Sensor wurde in eine Nylonkapsel eingebettet und mit einem Handgriff aus Stahlrohr versehen. Durch den StahlrohrHandgriff wurde die Verkabelung geführt. (b) Der Sensor wurde auf die okklusale Oberfläche des zweiten oder dritten Prämolaren des Unterkiefers aufgesetzt und während der Kaubewegungen in dieser Position gehalten.

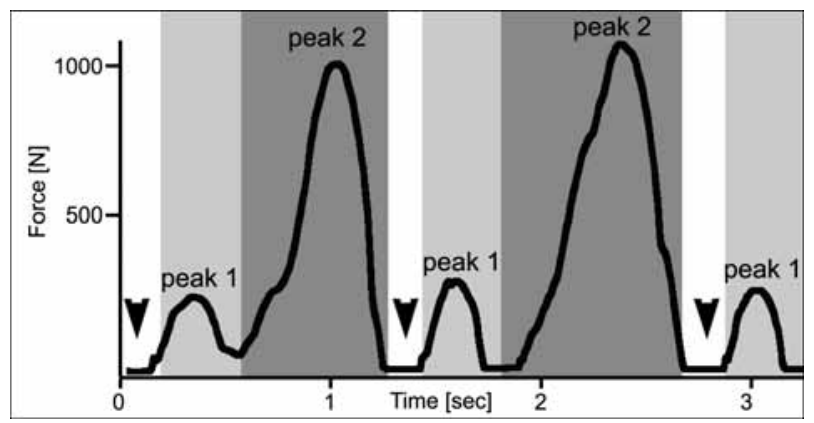

Fig 4 The recorded force time graphs showed a periodical sequence of two distinct peaks (peak 1 and peak 2). There is an intermediate periode (arrow head) preceding peak 1 .

Die aufgezeichneten Kraft-Zeit-Kurven wiesen eine wiederkehrende Sequenz von zwei Peaks auf (Peak 1 and Peak 2). Ein Kurvenabschnitt ohne Kraftentwicklung (Pfeilkopf) ging Peak 1 voraus.

time was $0.27 \pm 0.08 \mathrm{sec}$, ranging between $0.13 \mathrm{sec}$ (horse $2,3,10)$ and $0.54 \mathrm{sec}$ (horse 10).

The mean force of peak 2 was $875 \pm 278 \mathrm{~N}$, ranging between $397 \mathrm{~N}$ (horse 3) and $1758 \mathrm{~N}$ (horse 10); the mean duration time was $0.59 \pm 0.13 \mathrm{sec}$, ranging between $0.25 \mathrm{sec}$ (horse 7) and $0.94 \mathrm{sec}$ (horse 8).

The entire sequence of intermediate period, peak 1, and peak 2 was referred to as one chewing cycle. The horses che-

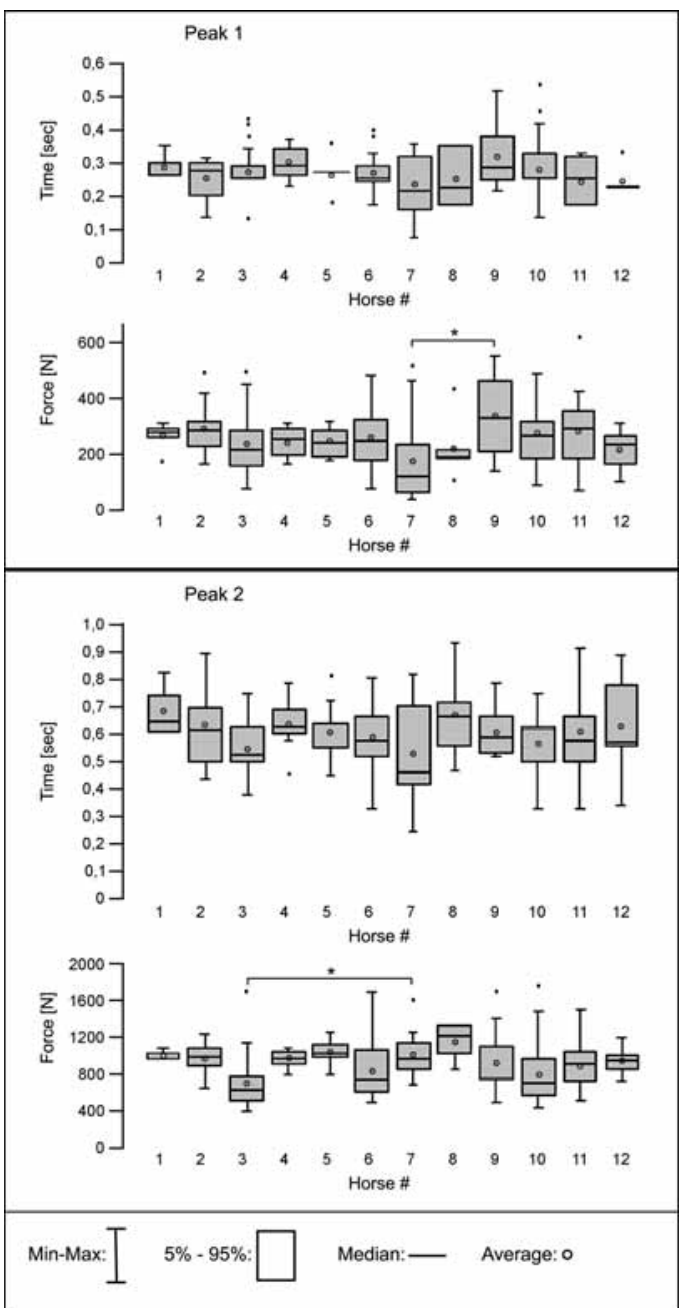

Fig 5 Duration time and force of peak 1 and peak 2 calculated for each examined horse. Please Note: Statistically, the values of the duration time were not significantly different; Multiple range test, Bonferroni correction. As for the masticatory forces, the values were significantly different $\left(^{*}\right)$ only for two comparisons, i.e. in horse 7 and horse 9 (peak 1) and in horse 3 and horse 7 (peak 2); Multiple range test, Bonferroni correction.

Daver und Kraft von Peak 1 und Peak 2, berechnet für jedes einzelne der untersuchten Pferde. Beachte: Die Werte für die Daver waren statistisch nicht signifikant unterschiedlich; Multiple range test, Bonferroni Korrektur. Bei den Werten für die Kaukraft lagen nur in zwei Fällen statistisch signifikante $\left({ }^{*}\right)$ Unterschiede vor: Pferd 7 und Pferd 9 (Peak 1); Pferd 3 und Pferd 7 (Peak 2), Multiple range test, Bonferroni Korrektur.

wed at a rate of $8 \pm 1$ chewing cycles per $10 \mathrm{sec}$. The maximum chewing force was $1758 \mathrm{~N}$ (horse 10).

\section{Discussion}

The records of the masticatory actions revealed a periodical sequence of chewing cycles with two different stages of force generation, represented by peak 1 (248 N, $0.27 \mathrm{sec}$ ) and by peak 2 (875 N, $0.59 \mathrm{sec})$. The first was shorter and weaker than the second. 
This pattern corresponds to the distinct masticatory motions of the jaw (see Fig. 7), which comprise three individual phases (opening stroke, closing stroke, and power stroke according to Collinson 1994, Tremaine 1997 and Baker 2005).

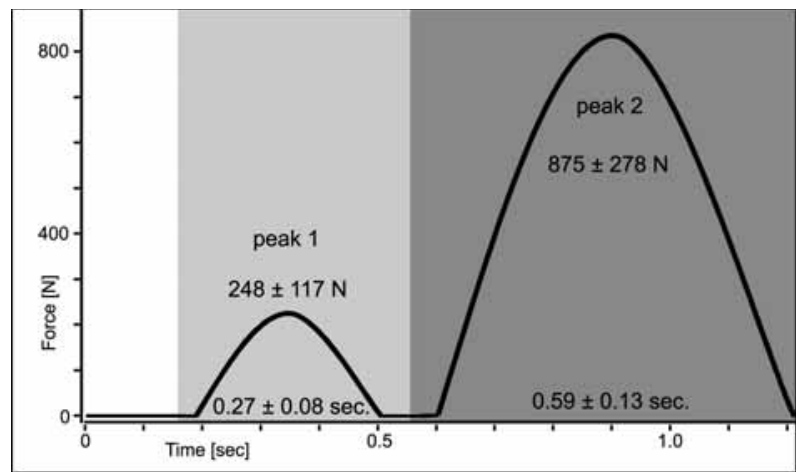

Fig 6 Mean values of duration time and force of peak 1 and peak 2, calculated for all examined horses.

Mittelwerte der Parameter Daver und Kraft, jeweils für Peak 1 und Peak 2, für alle untersuchten Pferde.

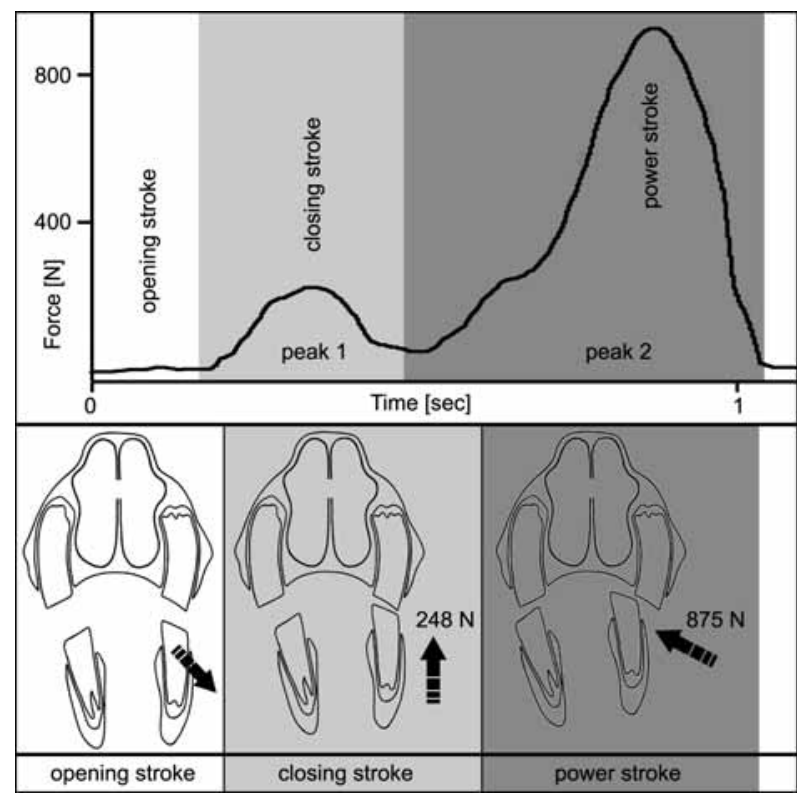

Fig 7 The recorded force time graph (on top) has two peaks. They represent the closing stroke (bottom, center) and the power stroke (bottom, right).

Die aufgezeichnete Kraft-Zeit-Kurve (obere Abbildung) weist zwei Peaks auf. Dieses Muster entspricht der Phasenabfolge im Kauzyklus (untere Abbildung).

Data on the duration of the power stroke and chewing rate have previously been recorded by electromyography of horses feeding on forage (Collinson 1994). The horses in our experiments chewed more slowly than the ones in that study, but with more emphasis on the power stroke. The chewing rate in our experiments was lower, i.e. 8 chewing cycles per $10 \mathrm{sec}$ (our data) vs. 11.5 chewing cycles per $10 \mathrm{sec}$ (Collison 1994), but the power stroke in our experiments was longer, i.e. $0.59 \mathrm{sec}$ (our data) vs. $0.53 \mathrm{sec}$. (Collison 1994). This effect might have been due to the hard consistency of the nylon capsule in which the sensor had been encased, and it has been shown for example that increased fiber content of forage results in decreased chewing rates (Collinson 1994). Ritter (1953) reported masticatory forces of $451 \mathrm{~N}$ (for the second premolars) and of $628 \mathrm{~N}$ (for the third premolars). However, due to the mechanical design of his equipment. In that experiment, two lever arms were pushed towards each other when the horse closed its mouth., these values did not represent the entire chewing cycle, but only the closing stroke. Ritter's (1953) measurements during the closing stroke $(451 \mathrm{~N}, 628 \mathrm{~N})$ fall between the values we measured for the closing stroke $(248 \pm 117 \mathrm{~N})$ and the power stroke $(875 \pm 278$ N).

\section{Conclusions}

In our experimental setting, the horses showed regular chewing cycles during the measuring procedure. The recorded force time graphs represent the amount of masticatory forces generated in each of the three distinct phases of the chewing cycle. When applied to mathematical models, these data will make it possible to identify the distribution of forces (1) within the tooth, (2) along the dental surface, and (3) in the periodontal suspensory apparatus. This can be performed once the position of the tooth in the alveolus has been elucidated (in a separate study).

As the site of measurement was restricted to the area of the second and third premolar teeth, it cannot be assumed that the strength of the recorded forces also applies to the entire cheek tooth battery. In consideration of mechanical principles we estimate that the masticatory forces are even higher in the caudal parts of the jaws. But this is also subject to further investigations.

\section{References}

Baker G. J. (2005): Dental Physiology. In: Equine Dentistry, 2nd edition. Elsevier/Saunders, Edinburgh and London

Collinson M. (1994): Food processing and digestibility in horses (Equus caballus). MD thesis, Clayton, Monash University

Frape D. (1990): Equine Nutrition and Feeding. Longman Scientific and Technical, New York

Ritter G. (1953): Kaukraft und Kaudruck des Pferdes. Dissertation, FU Berlin

Tremaine H. (1997): Dental care in horses. In Practice 19, 186-199 Wallraff W. (1943): Untersuchungen über die Kaukraft des Pferdes. Vet. Med. Diss. Humboldt-Universität Berlin

Dr. Carsten Staszyk

University of Veterinary Medicine Hannover

Institut of Anatomy

Bischofsholer Damm 15

D-30173 Hannover, Germany

carsten.staszyk@tiho-hannover.de 